\title{
Microwave-Assisted Synthesis of Some 1,3,4-Oxadiazole Derivatives and Evaluation of Their Antibacterial and Antifungal Activity
}

\author{
Deepak Swarnkar, Rakshit Ameta, and Ritu Vyas \\ Department of Chemistry, PAHER University, Udaipur, Rajasthan 313003, India \\ Correspondence should be addressed to Deepak Swarnkar; swaranakardeepak@gmail.com
}

Received 10 September 2014; Revised 18 November 2014; Accepted 18 November 2014; Published 3 December 2014

Academic Editor: Joseph E. Saavedra

Copyright (C) 2014 Deepak Swarnkar et al. This is an open access article distributed under the Creative Commons Attribution License, which permits unrestricted use, distribution, and reproduction in any medium, provided the original work is properly cited.

A series of substituted 1,3,4-oxadiazole derivatives (3a-f) and (6a-f) have been synthesized from diphenylacetic acid hydrazide under microwave irradiation in various reaction conditions. The structures of the synthesized compounds were assigned on the basis of elemental analysis, IR, and ${ }^{1} \mathrm{H}$ NMR. These targeted compounds have been tested for their antibacterial and antifungal activities compared to ampicillin and griseofulvin as standard drug. Compounds $\mathbf{3 a}, \mathbf{3 e}, \mathbf{3 f}, \mathbf{6 c}, \mathbf{6 d}, \mathbf{6 e}$, and $\mathbf{6} \mathbf{d}$ exhibited the maximum antibacterial activities while $\mathbf{3 b}, \mathbf{3 c}, \mathbf{3 d}, \mathbf{3 e}, \mathbf{6 a}, \mathbf{6 d}$, and $\mathbf{6 e}$ exhibited the maximum antifungal activities.

\section{Introduction}

Oxadiazole has occupied a unique place in the field of medicinal and pesticide chemistry due to its wide range of activities. Bhandari et al. [1] have reported the design, synthesis, and evaluation of anti-inflammatory, analgesic, and ulcerogenicity of novel S-substituted phenacyl-1,3,4-oxadiazole-2-thiol and Schiff bases of diclofenac acid as nonulcerogenic derivatives whereas Narayana et al. [2] have synthesized some new 2-(6-methoxy-2-naphthyl)-5-aryl-1,3,4-oxadiazoles as possible nonsteroidal anti-inflammatory and analgesic agents. Synthesis and evaluation of anti-inflammatory, analgesic, ulcerogenic, and lipid peroxidation properties of ibuprofen derivatives have been studied by Amir and Kumar [3] while Hui et al. [4] have carried out the synthesis and antibacterial activities of 1,3,4-oxadiazole derivatives containing 5methylisoxazole moiety.

1,3,4-Oxadiazole derivatives have been synthesized by Sahin et al. [5] and they have also studied their antifungal activity. Novel chiral and achiral benzenesulfonamides bearing 1,3,4-oxadiazole moieties have been synthesized by Zareef et al. [6] and studied for their antimalarial activity. Husain and Ajmal [7] have synthesized novel 1,3,4-oxadiazole derivatives and investigated their anticonvulsant properties. Burbuliene et al. [8] have reported the synthesis and anti-inflammatory activity of derivatives of 5-[(2-disubstituted amino-6-methylpyrimidin-4-yl)sulfanylmethyl]-3H-1,3,4-oxadiazole-2-thiones while Padmaja et al. [9] have studied the synthesis and antioxidant activity of disubstituted 1,3,4-oxadiazole, 1,3,4-thiadiazoles, and 1,2,4-triazoles.

El-Emam et al. [10] have synthesized certain 5-(1adamantyl)-2-substitutedthio-1-3-4-oxadiazoles and 5-(1adamantyl)-3-substituted aminomethyl-1,3,4-oxadiazoline2-thiones and studied their anti-HIV-1 activity whereas synthesis and antitumor activity of some new 1,3,4-oxadiazole, pyrazole, and pyrazolo[3,4-d]pyrimidine derivatives attached to 4-benzothiazole-2-yl phenyl moiety have been studied by El-Hamouly et al. [11].

Newton [12] patented the synthesis of novel N-aralkyl and N-heteroaralkyl amides of [1,3,4]-oxadiazole and [1,3,4] thiadiazole-carboxylic acids, which were further used for the preparation of herbicidal compositions containing compounds. He has developed a method of combating undesired plant growth using these compounds. Solak and 
Rollas [13] have reported the synthesis and antituberculosis activity of 2-(aryl/alkylamino)-5-(4-aminophenyl)-1,3,4thiadiazoles and their Schiff bases whereas Matysiak et al. [14] have studied synthesis and antiproliferative activity of some 5-substituted 2-(2,4-dihydroxyphenyl)-1,3,4thiadiazoles. Holla and coworker [15] carried out the synthesis of some new biologically active thiadiazolotriazinones while Radi et al. [16] have reported the discovery and SAR of 1,3,4-thiadiazole derivatives as potent Abl tyrosine kinase inhibitors and cytodifferentiating agents.

Microwave-assisted chemical synthesis plays an important role in pharmaceuticals and medicinal chemistry such as drug discovery. The microwave mediated organic reactions are environmentally friendly, safe, rapid, and high yield compared to conventional methods.

\section{Materials and Methods}

The melting points were determined in open capillary tubes and are uncorrected. The IR spectra were recorded on PerkinElmer 157 spectrometer using $\mathrm{KBr}$ pellets. The ${ }^{1} \mathrm{H}$ NMR spectra were scanned on a DRX-300 MHz spectrometer $(300 \mathrm{MHz})$ in $\mathrm{CDCl}_{3} / \mathrm{DMSO}-\mathrm{d} 6$ using TMS as internal standard and chemical shifts are expressed in $\delta \mathrm{ppm}$. Purity of synthesized compounds was checked by TLC using silica gel$\mathrm{G}$. Spots were exposed in an iodine chamber.

2.1. General Procedure for Preparation of Compounds (3af). The synthetic strategy of the target compounds is illustrated in Scheme 1. The diphenylacetic acid (1) (0.001 mol), hydrazine hydrate $(0.001 \mathrm{~mol})$, and ethanol $(10 \mathrm{~mL})$ were exposed in microwave at $5 \mathrm{sec}$. intervals. The specific reaction time of $3 \mathrm{~min}$. was observed for diphenylacetic acid hydrazide (2). The product obtained was cooled in ice cooled water. The precipitate of the product obtained was filtered, washed with water, and purified by recrystallization from ethanol. Thereafter, the compound diphenylacetic acid hydrazide (2) $(0.001 \mathrm{~mol})$ and substituted aromatic acids $(0.001 \mathrm{~mol})$ were added together portionwise along with phosphorus oxychloride. After addition of these reactants, the reaction mixture was kept at room temperature for $5 \mathrm{~min}$. Further, $3 \mathrm{~g}$ silica gel was added to it and it was properly mixed. It was irradiated in microwave at $5 \mathrm{sec}$. intervals. The specific reaction time of $2 \mathrm{~min}$. was observed for compounds (3a-f). The product obtained was kept in crushed ice overnight. Next day, it was filtered, dried, and purified by recrystallization using ethanol. The completion of reaction was monitored by TLC method. The compounds (3a-f) were characterized with elemental analysis, IR, and NMR spectral data.

2-[5-(Diphenylmethyl)-1,3,4-oxadiazol-2-yl]aniline (3a). Yield $78 \%$, m.p. $115^{\circ} \mathrm{C}$; IR (KBr) cm ${ }^{-1}$ : $1615(\mathrm{C}=\mathrm{N}), 1218$ (C-O-C), 3048 (Ar-CH str.); ${ }^{1} \mathrm{H}$ NMR (DMSO d 6 ) $\delta: 5.31$ (1H, CH), 7.08-7.21 (Ar-H); Anal. Calcd. for $\mathrm{C}_{21} \mathrm{H}_{17} \mathrm{~N}_{3} \mathrm{O}$ : C, 77.04; $\mathrm{H}$, 5.23; N, 12.84\% Found: C, 77.01; H, 5.18; N, 12.79\%.

3-[5-(Diphenylmethyl)-1,3,4-oxadiazol-2-yl]-4-(trifluoromethyl)pyridine (3b). Yield $72 \%$, m.p. $110^{\circ} \mathrm{C}$; IR $(\mathrm{KBr}) \mathrm{cm}^{-1}$ :
$1621(\mathrm{C}=\mathrm{N}), 1214$ (C-O-C), 3042 (Ar-CH str.); ${ }^{1} \mathrm{H}$ NMR $\left(\mathrm{DMSO} \mathrm{d}_{6}\right) \delta: 5.29(1 \mathrm{H}, \mathrm{CH}), 7.12-7.28(\mathrm{Ar}-\mathrm{H})$; Anal. Calcd. for $\mathrm{C}_{21} \mathrm{H}_{14} \mathrm{~F}_{3} \mathrm{~N}_{3} \mathrm{O}$ : C, 66.14; $\mathrm{H}, 3.70 ; \mathrm{N}, 11.02 \%$ Found: $\mathrm{C}$, $66.02 ; \mathrm{H}, 3.62 ; \mathrm{N}, 11.07 \%$.

2-(Diphenylmethyl)-5-phenyl-1,3,4-oxadiazole (3c). Yield 79\%, m.p. $112^{\circ} \mathrm{C}$; IR (KBr) cm ${ }^{-1}$ : $1625(\mathrm{C}=\mathrm{N}), 1212(\mathrm{C}-\mathrm{O}-\mathrm{C}), 3047$ (Ar-CH str.); ${ }^{1} \mathrm{H}$ NMR (DMSO d 6 ) $\delta: 5.33(1 \mathrm{H}, \mathrm{CH}), 7.06-$ $7.25(\mathrm{Ar}-\mathrm{H})$; Anal. Calcd. for $\mathrm{C}_{21} \mathrm{H}_{16} \mathrm{~N}_{2} \mathrm{O}$ : C, 80.75; H, 5.16; N, 8.97\%. Found: C, 80.67; H, 5.09; N, 8.90\%.

2-[5-(Diphenylmethyl)-1,3,4-oxadiazol-2-yl]phenol(3d). Yield $75 \%$, m.p. $117^{\circ} \mathrm{C}$ IR (KBr) cm ${ }^{-1}$ : $1618(\mathrm{C}=\mathrm{N}), 1216(\mathrm{C}-\mathrm{O}-\mathrm{C})$, 3045 (Ar-CH str.); ${ }^{1} \mathrm{H}$ NMR (DMSO d 6 ) $\delta: 5.35(1 \mathrm{H}, \mathrm{CH})$, 7.09-7.29 (Ar-H); Anal. Calcd. for $\mathrm{C}_{21} \mathrm{H}_{16} \mathrm{~N}_{2} \mathrm{O}_{2}$ : C, 76.81; $\mathrm{H}$, $4.91 ; \mathrm{N}, 8.53 \%$. Found: C, 76.74; H, 4.86; N, 8.47\%.

2-(Diphenylmethyl)-5-[2-phenylethenyl]-1,3,4-oxadiazole (3e). Yield 76\%, m.p. $112^{\circ} \mathrm{C}$; IR (KBr) cm $\mathrm{cm}^{-1}$ : $1620(\mathrm{C}=\mathrm{N}), 1219(\mathrm{C}-$ $\mathrm{O}-\mathrm{C}), 3049$ (Ar-CH str.); ${ }^{1} \mathrm{H}$ NMR (DMSO d 6 ) $\delta: 5.28(1 \mathrm{H}$, $\mathrm{CH})$, 7.14-7.30 (Ar-H); Anal. Calcd. for $\mathrm{C}_{23} \mathrm{H}_{18} \mathrm{~N}_{2} \mathrm{O}$ : C, 81.63; H, 5.36; N, 8.28\%. Found: C, 81.56; H, 5.31; N, 8.24\%.

2-Adamantan-1-yl-5-benzhydryl-[1,3,4]oxadiazole (3f). Yield 81\%, m.p. $116^{\circ} \mathrm{C}$; IR (KBr) cm ${ }^{-1}$ : $1619(\mathrm{C}=\mathrm{N}), 1211$ (C-O-C), 3041 (Ar-CH str.); ${ }^{1} \mathrm{H}$ NMR (DMSO d 6 ) $\delta: 5.36(1 \mathrm{H}, \mathrm{CH})$, 7.10-7.32 (Ar-H); Anal. Calcd. for $\mathrm{C}_{25} \mathrm{H}_{26} \mathrm{~N}_{2} \mathrm{O}$ : C, 81.05; $\mathrm{H}$, 7.07; N, 7.56\%. Found: C, 81.01; H, 7.00; N, 7.49\%.

2.2. General Procedure for Preparation of Compounds (6a-f). A mixture of diphenylacetic acid hydrazide (2) (0.001 mol), $\mathrm{KOH}(0.001 \mathrm{~mol})$, and $\mathrm{CS}_{2}(5 \mathrm{~mL})$ in ethanol $(10 \mathrm{~mL})$ was exposed to microwave at $5 \mathrm{sec}$. intervals. The specific reaction time of $3 \mathrm{~min}$. was observed for 5-(diphenylmethyl)-1,3,4oxadiazole-2-thiol (5). This reaction mixture was cooled and acidified with dil. $\mathrm{HCl}$. The precipitate of product obtained was filtered, washed with water, and purified by recrystallization from ethanol. Thereafter, the compound (5) $(0.001 \mathrm{~mol})$ was added to the solution of $\mathrm{NaOH}(0.001 \mathrm{~mol})$ and ethanol $(10 \mathrm{~mL})$ and these were mixed properly. Further, 2-chloro- $N$ (substituted phenyl)-acetamides (4) (0.001 mol) was added portionwise in the above reaction mixture. Then, this reaction mixture was irradiated with microwave at $5 \mathrm{sec}$. intervals for specific time (1 min.) to yield compound $\mathbf{6 a}-\mathbf{f}$. The product obtained was cooled. The precipitate of product was filtered, washed with water, and purified by recrystallization from ethanol.

2-(5-Benzhydryl-[1,3,4]oxadiazol-2-ylsulfanyl)-N-p-tolyl-acetamide (6a). Yield $77 \%$, m.p. $115^{\circ} \mathrm{C}$; IR $(\mathrm{KBr}) \mathrm{cm}^{-1}: 3315(\mathrm{NH})$, $1595(\mathrm{C}=\mathrm{N}), 1660(\mathrm{C}=\mathrm{O}), 1240$ (C-O-C), 3042 (Ar-CH str.); ${ }^{1} \mathrm{H}$ NMR (DMSO d 6 ) $\delta: 8.61(1 \mathrm{H}, \mathrm{CONH}), 5.32(1 \mathrm{H}$, $\mathrm{CH}), 3.92\left(\mathrm{CH}_{2} \mathrm{CO}\right), 7.10-7.22(\mathrm{Ar}-\mathrm{H})$; Anal. Calcd. for $\mathrm{C}_{24} \mathrm{H}_{21} \mathrm{~N}_{3} \mathrm{O}_{2}$ S: C, 69.37; H, 5.09; N, 10.11\%. Found: C, 69.32; $\mathrm{H}, 5.02$; N, $10.06 \%$.

2-(5-Benzhydryl-[1,3,4]oxadiazol-2-ylsulfanyl)-N-(4-chlorophenyl)-acetamide (6b). Yield 81\%, m.p. $112^{\circ} \mathrm{C}$; IR (KBr) $\mathrm{cm}^{-1}$ : $3318(\mathrm{NH}), 1599(\mathrm{C}=\mathrm{N}), 1666(\mathrm{C}=\mathrm{O}), 1237(\mathrm{C}-\mathrm{O}-\mathrm{C}), 3039$ 
<smiles>[R]c1nnc(C(c2ccccc2)c2ccccc2)o1</smiles>

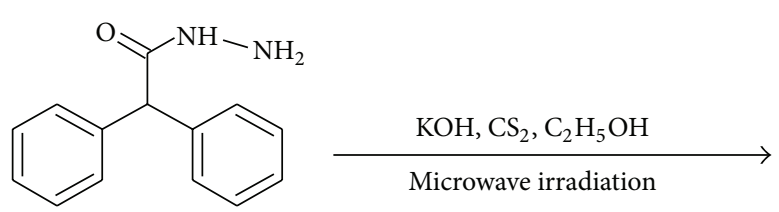<smiles>Sc1nnc(C(c2ccccc2)c2ccccc2)o1</smiles>

(2)

(4)<smiles>Sc1nnc(C(c2ccccc2)c2ccccc2)o1</smiles>

(4)<smiles>[R]c1ccc(NC(=O)CCl)cc1</smiles>

(5)

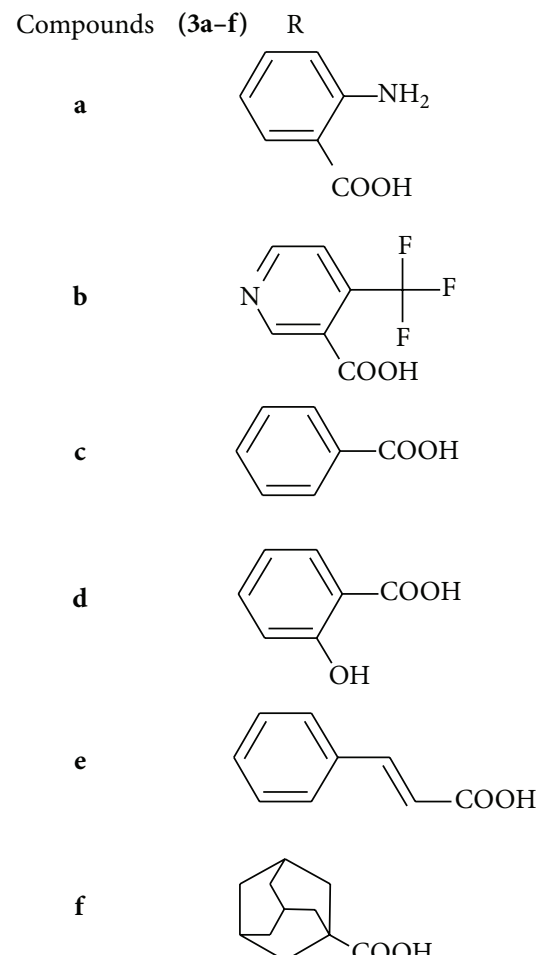

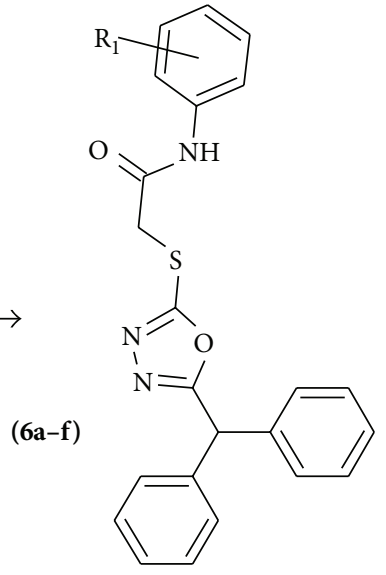

a<smiles>CC(C)(C)ON=O</smiles>

(6a-f)<smiles>Cc1ccc(N)cc1</smiles><smiles>Nc1ccc(Cl)cc1</smiles>

c<smiles>COc1ccc(N)cc1</smiles>

d<smiles>Nc1ccc(O)cc1</smiles>

e<smiles>Nc1ccc([N+](=O)[O-])cc1</smiles>

f<smiles>Nc1ccc(C(=O)O)cc1</smiles>

Scheme 1: Synthesis of compounds (3a-f) and (6a-f). 
(Ar-CH str.); ${ }^{1} \mathrm{H}$ NMR (DMSO d $\left.\mathrm{d}_{6}\right) \delta: 8.64(1 \mathrm{H}, \mathrm{CONH})$, $5.30(1 \mathrm{H}, \mathrm{CH}), 3.96\left(\mathrm{CH}_{2} \mathrm{CO}\right)$, 7.14-7.26 (Ar-H); Anal. Calcd. for $\mathrm{C}_{23} \mathrm{H}_{18} \mathrm{ClN}_{3} \mathrm{O}_{2} \mathrm{~S}$ : C, 63.37; $\mathrm{H}, 4.16$;, 9.64\%. Found: $\mathrm{C}$, $63.33 ; \mathrm{H}, 4.09 ; \mathrm{N}, 9.57 \%$.

2-(5-Benzhydryl-[1,3,4]oxadiazol-2-ylsulfanyl)-N-(4-methoxy-phenyl)-acetamide (6c). Yield 74\%, m.p. $121^{\circ} \mathrm{C}$; IR $(\mathrm{KBr}) \mathrm{cm}^{-1}$ : $3332(\mathrm{NH}), 1609(\mathrm{C}=\mathrm{N}), 1662(\mathrm{C}=\mathrm{O}), 1242$ (C-O-C), 3045 (Ar-CH str.); ${ }^{1} \mathrm{H}$ NMR (DMSO d $\mathrm{d}_{6}$ ) $\delta$ : $8.66(1 \mathrm{H}, \mathrm{CONH}), 5.35(1 \mathrm{H}, \mathrm{CH}), 3.93\left(\mathrm{CH}_{2} \mathrm{CO}\right), 7.08-7.29$ (Ar-H); Anal. Calcd. for $\mathrm{C}_{24} \mathrm{H}_{21} \mathrm{~N}_{3} \mathrm{O}_{3} \mathrm{~S}$ : C, 66.80; H, 4.91; N, 9.74\%. Found: C, 66.75; H, 4.80; N, 9.70\%.

2-(5-Benzhydryl-[1,3,4]oxadiazol-2-ylsulfanyl)-N-(4-hydroxy-phenyl)-acetamide (6d). Yield 82\%, m.p. $132^{\circ} \mathrm{C}$; IR $(\mathrm{KBr}) \mathrm{cm}^{-1}: 3341(\mathrm{NH}), 1597(\mathrm{C}=\mathrm{N}), 1659(\mathrm{C}=\mathrm{O}), 1238(\mathrm{C}-$ $\mathrm{O}-\mathrm{C}), 3047$ (Ar-CH str.); ${ }^{1} \mathrm{H}$ NMR (DMSO d 6 ) $\delta: 8.58(1 \mathrm{H}$, $\mathrm{CONH}), 5.37(1 \mathrm{H}, \mathrm{CH}), 3.99\left(\mathrm{CH}_{2} \mathrm{CO}\right), 7.12-7.27(\mathrm{Ar}-\mathrm{H})$; Anal. Calcd. for $\mathrm{C}_{23} \mathrm{H}_{19} \mathrm{~N}_{3} \mathrm{O}_{3} \mathrm{~S}$ : C, 66.17; H, 4.59; N, 10.07\%; Found: C, 66.11; H, 4.52; N, 10.02\%.

2-(5-Benzhydryl-[1,3,4]oxadiazol-2-ylsulfanyl)-N-(4-nitrophenyl)-acetamide (6e). Yield 77\%, m.p. $126^{\circ} \mathrm{C}$; IR $(\mathrm{KBr}) \mathrm{cm}^{-1}$ : $3336(\mathrm{NH}), 1610(\mathrm{C}=\mathrm{N}), 1665(\mathrm{C}=\mathrm{O}), 1246$ (C-O-C), 3049 (Ar-CH str.); ${ }^{1} \mathrm{H}$ NMR (DMSO d $\mathrm{d}_{6}$ ) $\delta$ : $8.56(1 \mathrm{H}, \mathrm{CONH}), 5.33(1 \mathrm{H}, \mathrm{CH}), 3.89\left(\mathrm{CH}_{2} \mathrm{CO}\right), 7.10-7.30$ (Ar-H); Anal. Calcd. for $\mathrm{C}_{23} \mathrm{H}_{18} \mathrm{~N}_{4} \mathrm{O}_{4} \mathrm{~S}$ : C, 61.87; H, 4.06; N, 12.55\%; Found: C, 61.78; H, 4.01; N, 12.49\%.

4-[2-(5-Benzhydryl-[1,3,4]oxadiazol-2-ylsulfanyl)-acetylamino]-benzoic acid (6f). Yield 83\%, m.p. $129^{\circ} \mathrm{C}$; IR (KBr) cm ${ }^{-1}$ : $3344(\mathrm{NH}), 1594(\mathrm{C}=\mathrm{N}), 1662(\mathrm{C}=\mathrm{O}), 1241(\mathrm{C}-\mathrm{O}-\mathrm{C}), 3043$ (Ar-CH str.); ${ }^{1} \mathrm{H}$ NMR (DMSO d $\mathrm{d}_{6}$ ) $\delta: 8.63(1 \mathrm{H}, \mathrm{CONH}), 5.31$ $(1 \mathrm{H}, \mathrm{CH}), 3.90\left(\mathrm{CH}_{2} \mathrm{CO}\right), 7.11-7.28(\mathrm{Ar}-\mathrm{H})$; Anal. Calcd. for $\mathrm{C}_{24} \mathrm{H}_{19} \mathrm{~N}_{3} \mathrm{O}_{4} \mathrm{~S}$ : C, 64.71; H, 4.30; N, 9.43\%. Found: C, 64.62; $\mathrm{H}, 4.24 ; \mathrm{N}, 9.36 \%$.

\section{Results and Discussion}

The starting compound diphenylacetic acid hydrazide (2) reacts with substituted aromatic acids and $\mathrm{POCl}_{3}$ under microwave irradiation to give $(\mathbf{3 a}-\mathbf{f})$. Their structures were established on the basis of IR and ${ }^{1} \mathrm{H}$ NMR spectral data. The IR spectra of (3a-f) exhibited absorption bands at 1615$1621 \mathrm{~cm}^{-1}$ due to $\mathrm{C}=\mathrm{N}$ stretching vibration. The peak at $1211-1219 \mathrm{~cm}^{-1}$ appeared due to $\mathrm{C}-\mathrm{O}-\mathrm{C}$ stretching vibration. The ${ }^{1} \mathrm{H}$ NMR spectra of these compounds revealed signals at $\delta$ $=5.28-5.36 \mathrm{ppm}$ showing the presence of $\mathrm{CH}$ proton while a multiplet of aromatic protons at $\delta=7.06-7.30 \mathrm{ppm}$ confirmed the presence of oxadiazole ring.

A mixture of compound 5-(diphenylmethyl)-1,3,4oxadiazole-2-thiol (5), solution of $\mathrm{NaOH}$, ethanol, and 2chloro- $N$-(substitutedphenyl)-acetamides (4) was irradiated in microwave to afford compounds (6a-f). The compounds showed absorption peak at $3318-3344 \mathrm{~cm}^{-1}$ due to $\mathrm{NH}$ stretching vibrations. The peak at $1238-1246 \mathrm{~cm}^{-1}$ appeared due to $\mathrm{C}-\mathrm{O}-\mathrm{C}$ stretching vibrations, $\mathrm{C}=\mathrm{O}$ at $1659-1666 \mathrm{~cm}^{-1}$ and $\mathrm{C}=\mathrm{N}$ at $1594-1610 \mathrm{~cm}^{-1}$. The ${ }^{1} \mathrm{H}$ NMR spectra of these compounds displayed a singlet at $\delta=5.31-5.37$ ppm showing the presence of $\mathrm{CH}$ proton. The $\mathrm{CH}_{2} \mathrm{CO}$ protons were observed as singlet at $\delta=3.90-3.99 \mathrm{ppm}$ confirming the formation of acetamide derivatives. The $\mathrm{CONH}$ proton was observed as broad signals at $\delta=8.58-8.66 \mathrm{ppm}$ and multiplets of aromatic protons at $\delta=7.08-7.30 \mathrm{ppm}$ confirmed the formation of oxadiazole ring.

The results indicate that compounds show batter antibacterial and antifungal activity. For antibacterial activity, the compound $\mathbf{3 f}$ exhibits good active against E. coli; $\mathbf{3 e}, \mathbf{3 f}$, and 6 e exhibit good active against $S$. aureus showing MBC of $50 \mu \mathrm{g} / \mathrm{mL}$; $\mathbf{3 a}, \mathbf{6 c}, \mathbf{6 d}$, and $\mathbf{6 e}$ exhibit good active against P. aeruginosa showing $\mathrm{MBC}$ of $100 \mu \mathrm{g} / \mathrm{mL}$. For antifungal activity, the compounds $\mathbf{3 b}$ and $\mathbf{3} \mathbf{f}$ exhibit good active against C. albicans; $3 c, 3 e, 6 \mathbf{a}$, and $6 \mathbf{e}$ exhibit good active against $A$. niger; 3c, 3d, 3e, 3f, and $\mathbf{6 d}$ exhibit good active against $A$. clavatus showing $\mathrm{MBC}$ of $100 \mu \mathrm{g} / \mathrm{mL}$.

\section{Antibacterial and Antifungal Activity}

All the compounds, that is, (3a-f) and (6a-f), were tested for antibacterial activity against Escherichia coli (Gram negative), Staphylococcus aureus (Gram positive), and Pseudomonas aeruginosa (Gram positive) bacteria and antifungal activity against three fungal strains Candida albicans, Aspergillus niger, and Aspergillus clavatus. Ampicillin and griseofulvin were used as standard drugs for antibacterial and antifungal activity, respectively.

Minimal bactericidal concentration (MBC) and minimal fungicidal concentration (MFC) were determined using Broth dilution method. Serial dilution for primary and secondary screening, material, and method was followed as per NCCLS-1992 manual [17].

A stock solution was prepared of each drug $(2000 \mu \mathrm{g} / \mathrm{mL}$ concentration). In primary screening, 1000, 500, 250, and $125 \mu \mathrm{g} / \mathrm{mL}$ concentrations of the synthesized drugs were taken. The synthesized drugs found active in this primary screening were further tested in a second set of dilution against all microorganisms. The drugs found active in primary screening were similarly diluted to obtain 100,50 , $25,12.5,6.250,3.125$, and $1.5625 \mu \mathrm{g} / \mathrm{mL}$ concentrations. The standard drug used in the present study is ampicillin for evaluating antibacterial activity which showed 50, 50, and $100 \mu \mathrm{g} / \mathrm{mL}$ MBC against S. aureus, E. coli, and P. aeruginosa, respectively. Griseofulvin was used as the standard drug for antifungal activity, which showed $100 \mu \mathrm{g} / \mathrm{mL}$ MFC against all the species, used for the antifungal activity. The results of antimicrobial and antifungal activities of all the synthesized compounds are shown in Table 1.

\section{Conclusion}

Microwave-assisted organic synthesis is an eco-friendly, fast, efficient, and safe method and gives higher yield of product for synthesis of 1,3,4-oxadiazole derivatives. All the compounds show good antibacterial and antifungal activity against microorganisms used. 
TABLE 1: Antibacterial and antifungal activity of all the synthesized compounds.

\begin{tabular}{|c|c|c|c|c|c|c|}
\hline \multirow{3}{*}{ Sr. number } & \multicolumn{3}{|c|}{ Minimal bactericidal concentration $(\mathrm{MBC})(\mu \mathrm{g} / \mathrm{mL})$} & \multicolumn{3}{|c|}{ Minimal fungicidal concentration (MFC) $(\mu \mathrm{g} / \mathrm{mL})$} \\
\hline & \multicolumn{2}{|c|}{ Gram negative } & \multirow{2}{*}{$\begin{array}{c}\text { Gram positive } \\
\text { S. aureus }\end{array}$} & \multirow{2}{*}{ C. albicans } & \multirow{2}{*}{ A. niger } & \multirow{2}{*}{ A. clavatus } \\
\hline & E. coli & P. aeruginosa & & & & \\
\hline $3 a$ & 100 & 100 & 100 & 500 & 250 & 500 \\
\hline $3 \mathbf{b}$ & 250 & 250 & 500 & 100 & 500 & 250 \\
\hline $3 c$ & 500 & 250 & 250 & 250 & 100 & 100 \\
\hline $3 d$ & 500 & 250 & 250 & 250 & 250 & 100 \\
\hline $3 e$ & 250 & 250 & 50 & 500 & 100 & 100 \\
\hline $3 f$ & 50 & 250 & 50 & 100 & 500 & 100 \\
\hline $6 a$ & 500 & 250 & 250 & 250 & 100 & 250 \\
\hline $6 b$ & 100 & 250 & 500 & 500 & 250 & 500 \\
\hline $6 c$ & 100 & 100 & 500 & 500 & 250 & 250 \\
\hline $6 d$ & 250 & 100 & 100 & 250 & 250 & 100 \\
\hline $6 e$ & 500 & 100 & 50 & 250 & 100 & 500 \\
\hline $6 f$ & 100 & 100 & 250 & 500 & 500 & 250 \\
\hline S.D. & 50 & 100 & 50 & 100 & 100 & 100 \\
\hline
\end{tabular}

\section{Conflict of Interests}

The authors declare that there is no conflict of interests regarding the publication of this paper.

\section{Acknowledgments}

The authors are thankful to the Head of Department of Chemistry, Pacific University, Udaipur (Raj.), for providing laboratory facilities and the Head of Department of Pharmacy for providing spectral and analytical data.

\section{References}

[1] S. V. Bhandari, K. G. Bothara, M. K. Raut, A. A. Patil, A. P. Sarkate, and V. J. Mokale, "Design, synthesis and evaluation of anti-inflammatory, analgesic and ulcerogenicity studies of novel S-substituted phenacyl-1,3,4-oxadiazole-2-thiol and Schiff bases of diclofenac acid as nonulcerogenic derivatives," Bioorganic and Medicinal Chemistry, vol. 16, no. 4, pp. 1822-1831, 2008.

[2] B. Narayana, K. K. V. Raj, B. V. Ashalatha, and N. S. Kumari, "Synthesis of some new 2-(6-methoxy-2-naphthyl)-5-aryl1,3,4-oxadiazoles as possible non-steroidal anti-inflammatory and analgesic agents," Archiv der Pharmazie, vol. 338, no. 8, pp. 373-377, 2005.

[3] M. Amir and S. Kumar, "Synthesis and evaluation of antiinflammatory, analgesic, ulcerogenic and lipid peroxidation properties of ibuprofen derivatives," Acta Pharmaceutica, vol. 57, no. 1, pp. 31-45, 2007.

[4] X.-P. Hui, C.-H. Chu, Z.-Y. Zhang, Q. Wang, and Q. Zhang, "Synthesis and antibacterial activities of 1,3,4-oxadiazole derivatives containing 5-methylisoxazole moiety," Indian Journal of Chemistry B, vol. 41, no. 10, pp. 2176-2179, 2002.

[5] G. Şahin, E. Palaska, M. Ekizoğlu, and M. Özalp, "Synthesis and antimicrobial activity of some 1,3,4-oxadiazole derivatives," Farmaco, vol. 57, no. 7, pp. 539-542, 2002.
[6] M. Zareef, R. Iqbal, N. G. De Dominguez et al., "Synthesis and antimalarial activity of novel chiral and achiral benzenesulfonamides bearing 1,3,4-oxadiazole moieties," Journal of Enzyme Inhibition and Medicinal Chemistry, vol. 22, no. 3, pp. 301-308, 2007.

[7] A. Husain and M. Ajmal, "Synthesis of novel 1,3,4-oxadiazole derivatives and their biological properties," Acta Pharmaceutica, vol. 59, no. 2, pp. 223-233, 2009.

[8] M. M. Burbuliene, V. Jakubkiene, G. Mekuskiene, E. Udrenaite, R. Smicius, and P. Vainilavicius, "Synthesis and anti-inflammatory activity of derivatives of 5-[(2-disubstitutedamino-6-methyl-pyrimidin-4-yl)-sulfanylmethyl]-3H-1,3, 4-oxadiazole-2-thiones," Farmaco, vol. 59, no. 10, pp. 767-774, 2004.

[9] A. Padmaja, C. Rajasekhar, A. Muralikrishna, and V. Padmavathi, "Synthesis and antioxidant activity of disubstituted 1,3,4-oxadiazole, 1,3,4-thiadiazoles and 1,2,4-triazoles," Journal of Chemical and Pharmaceutical Research, vol. 4, no. 1, pp. 294302, 2012.

[10] A. A. El-Emam, O. A. Al-Deeb, M. Al-Omar, and J. Lehmann, "Synthesis, antimicrobial, and anti-HIV-1 activity of certain 5-(1-adamantyl)-2-substituted thio-1,3,4-oxadiazoles and 5(1-adamantyl)-3-substituted aminomethyl-1,3,4-oxadiazoline2-thiones," Bioorganic and Medicinal Chemistry, vol. 12, no. 19, pp. 5107-5113, 2004.

[11] W. S. El-Hamouly, K. M. Amin, S. A. El-Assaly, and E. A. A. El-Meguid, "Synthesis and antitumor activity of some new 1,3,4-oxadiazole, pyrazole and pyrazolo [3,4-d]pyrimidine derivatives attached to 4-benzothiazol-2-yl phenyl moiety," Der Pharma Chemica, vol. 3, no. 6, pp. 282-292, 2011.

[12] T. W. Newton, "Herbicidal[1,3,4] oxadiazoles and thiadiazoles," US 5591695 A, 1997.

[13] N. Solak and S. Rollas, "Synthesis and antituberculosis activity of 2-(aryl/alkylamino)-5-(4-aminophenyl)-1,3,4-thiadiazoles and their Schiff bases," Arkivoc, vol. 2006, no. 12, pp. 173-181, 2006.

[14] J. Matysiak, A. Nasulewicz, M. Pełczyńska, M. Świtalska, I. Jaroszewicz, and A. Opolski, "Synthesis and antiproliferative 
activity of some 5-substituted 2-(2,4-dihydroxyphenyl)-1,3,4thiadiazoles," European Journal of Medicinal Chemistry, vol. 41, no. 4, pp. 475-482, 2006.

[15] B. S. Holla, B. S. Rao, R. Gonsalves, B. K. Sarojini, and K. Shridhara, "Synthesis of some new biologically active thiadiazolotriazinones. Part III," Farmaco, vol. 57, no. 8, pp. 693-696, 2002.

[16] M. Radi, E. Crespan, G. Botta et al., "Discovery and SAR of 1,3,4thiadiazole derivatives as potent $\mathrm{Abl}$ tyrosine kinase inhibitors and cytodifferentiating agents," Bioorganic and Medicinal Chemistry Letters, vol. 18, no. 3, pp. 1207-1211, 2008.

[17] National Committee for Clinical Laboratory Standard, "Reference method for broth dilution antifungal susceptibility testing of yeasts," Approved Standard M27A, NCCLS, Wayne, Pa, USA, 1997. 

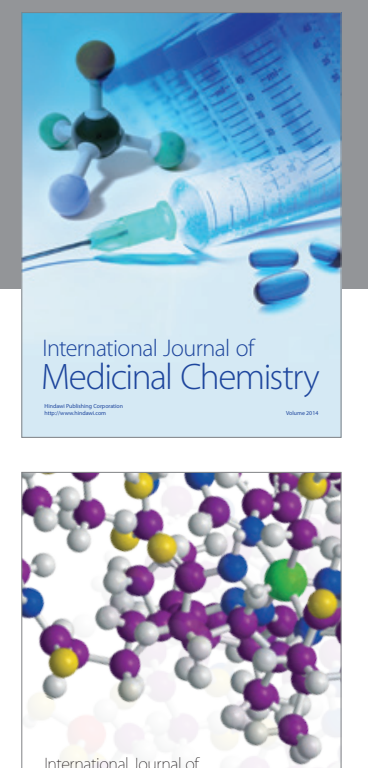

\section{Carbohydrate} Chemistry

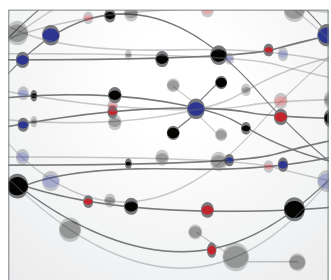

The Scientific World Journal
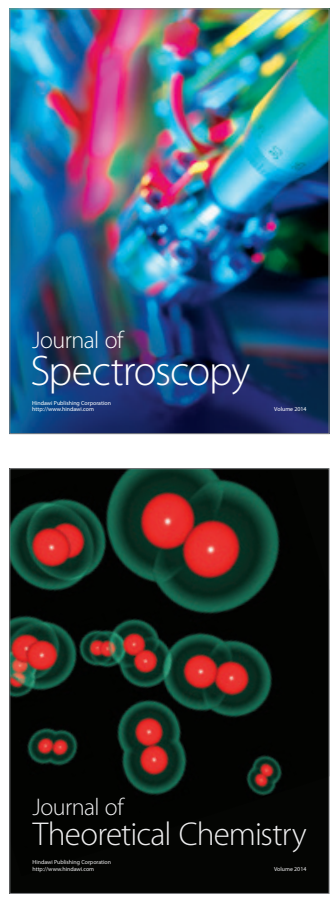
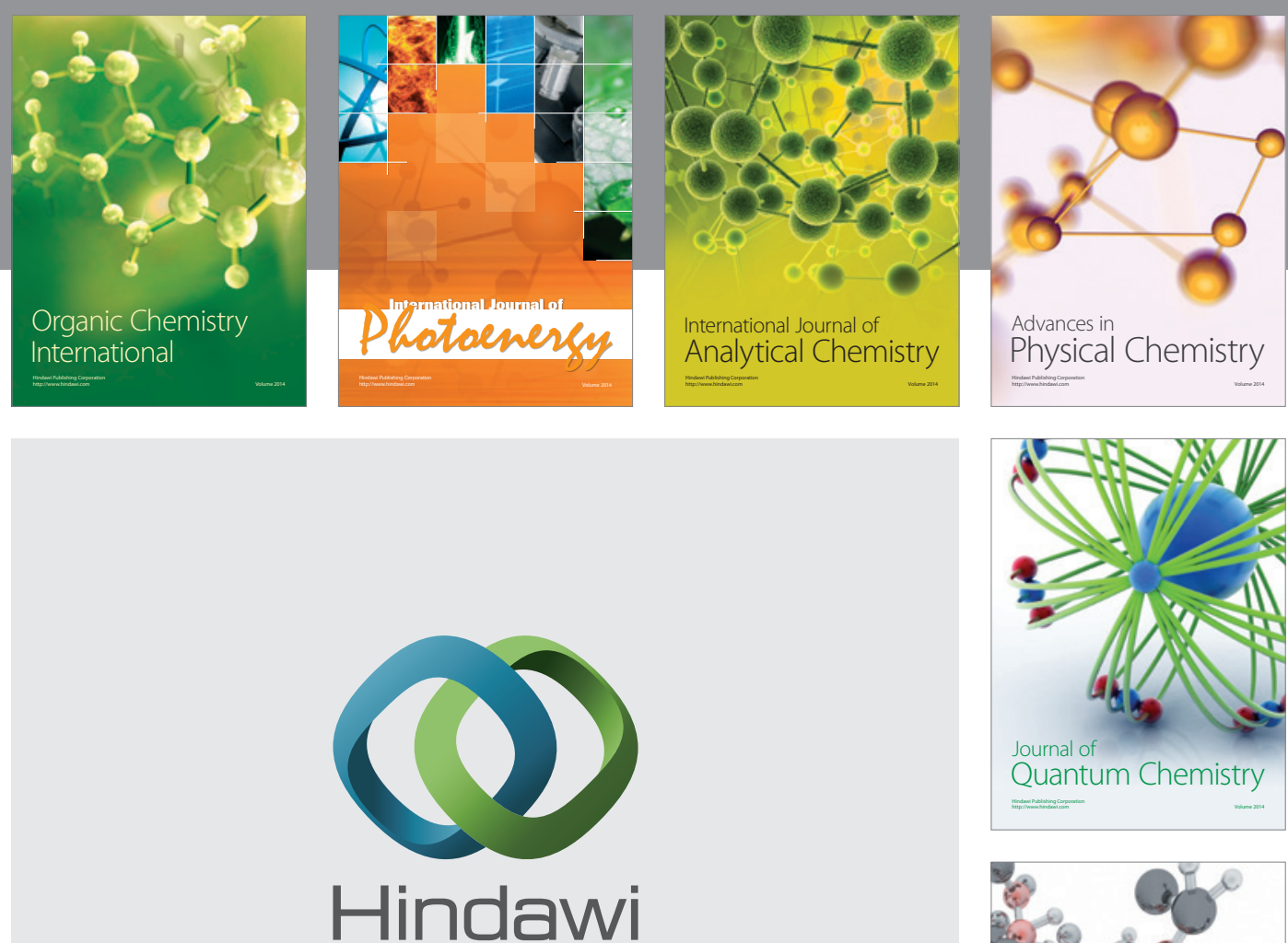

Submit your manuscripts at

http://www.hindawi.com

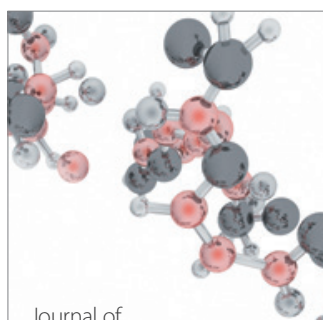

Analytical Methods

in Chemistry

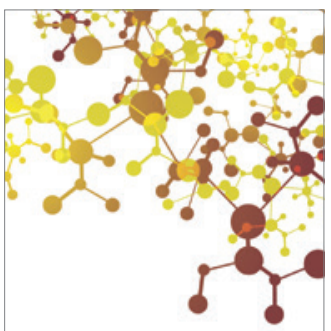

Journal of

Applied Chemistry

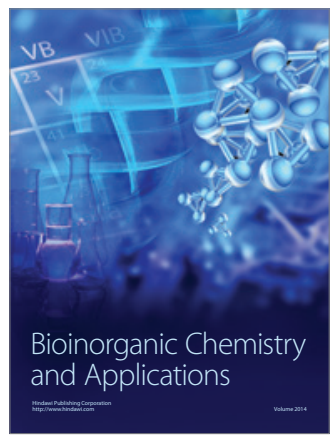

Inorganic Chemistry
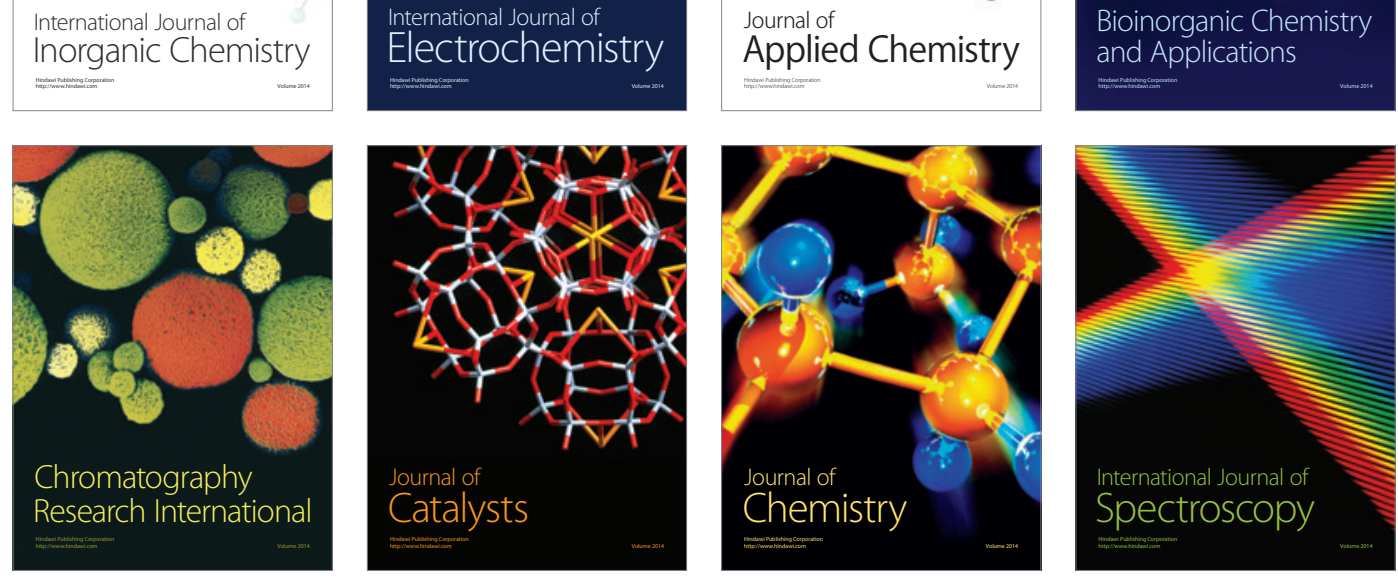